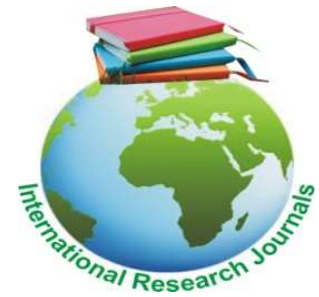

International Research Journal of Agricultural Science and Soil Science (ISSN: 2251-0044) Vol. 6(3) pp. 043-046, June, 2016

Available online http://www.interesjournals.org/lRJAS

DOI: http:/dx.doi.org/10.14303/irjas.2016.022

Copyright (C) 2016 International Research Journals

\title{
Review
}

\section{Measures against diseases of mung bean}

\author{
${ }^{1 *}$ Rahmonov J.X. and ${ }^{2}$ Sheraliev A.SH \\ 'Uzbekistan Protection of Plants Scientific Research Institute \\ ${ }^{2}$ Tashkent State Agrarian University \\ *Corresponding author's E-mail: jalilrahmanov76@mail.ru
}

\begin{abstract}
In irrigated farm lands of the Republic of Uzbekistan mung bean is grown as the main and repeated crop. In the component of bean $25-31 \%$ of protein, it requires needs of food of the population, its straw is nutrient feed for stock - breeding. How much the area extends which planted mung bean (it is given simple bean), it will play an essential role of malnutrition of protein.
\end{abstract}

Keywords: Diseases, Mung bean, Crop, Fungi diseases

\section{INTRODUCTION}

There are the Pobeda -104, Radost, Navruz, Kahrabo types have been localized. As the main crop it has root rotting, fading diseases are widely spread in the fields of bean breeding. Various diseases damage to the quality and rate of the crop in the area which is grown bean (Otaboeva and Tolipov, 1995, Otaboeva et al., 2000, Yunusov B 1995, Kurbonov GK 1995).

$20 / 25$ centner crop can be harvested from each hectare of leguminous crop of bean. Bean increases the fertility of the soil and at the same time enriches organic substances by collecting tuber bacteria and this is important to conserve the soil. There the research has been conducted which breeding bean as the repeated crop in irrigated lands. In the main lands which the bean sown fusarial wilt fading disease appears in the period of blooming and injured plant leaves become colourless and fade. Leguminous doesn't ripe fully, it can be taken easily from the soil. F.oxysporum f.sp. phaseoli types cause the disease. Fungi lives in the soil and enters the plant through seeds. Diseased organs of a plant turn to reddish violet color and its out layer is covered with fungi. Infection source is kept in the remain of a plant and soil) Chumakov AE 1974).

Grass and root rotting diseases are widely spread in all parts of the world and last chronically in the vegetation period, seed leaves and young seedlings damage much. The leaves of the injured plant turn yellow and fade, leguminous and corn become little, the plant doesn't grow well. Fusarium solani f.sp. phaseoli type causes the disease. Fungi come to organs through damaged wounds or directly through the health tissue. It enhances damage of the soil when replanted leguminous crops (Sheraliev et al., 2008).

For the type of "Yvakhar 45" in 3 dose of 50 and 100 $\mathrm{kg} / \mathrm{ha}$ of phosphorous fertilizer Ceprospora sp, Erysphi polygonii, Macrophomina phaseolina and Myrothecium roridum are used the damage of the disease decreased in the leaves of bean Colletotrichum sp, Erysiphi polygonii, Macrophomina phaseolina and Myrothecium phaseolina diseases decreased. In the past years sowing the bean interval and repeated appropriate to dry and hot condition of weather. When the average temperature of the soil is $20-25 \mathrm{c}$ it is the convenient time for fungi to develop which survive in the soil.

In 2014-2015 years in the fields of Jizzakh and Tashkent region where the bean sown after wheat, phytopathology research was conducted to study damage and spreading disease in the bean. In the field of experiments 150 ha Jizzakh region, 95 ha in Tashkent region as phythopotologic examination result were collected 496 plant which have had diseases and they analyzed mycologically in Tashkent State Agrarian biotechnology and phythapotology department. As the first figure showed in 2014 analyzed plants 63 or $12,7 \%$ fusarial root rotting, 162 or $32,7 \%$ fusarial fading, 45 or $9,1 \%$ anthracnose diseased. As the conducted researches in 2015 the results showed fusarial root rotting $10.1 \%$ fusarial fading $29.6 \%$ anthracnose $9 \%$. 


\section{Radost sort}

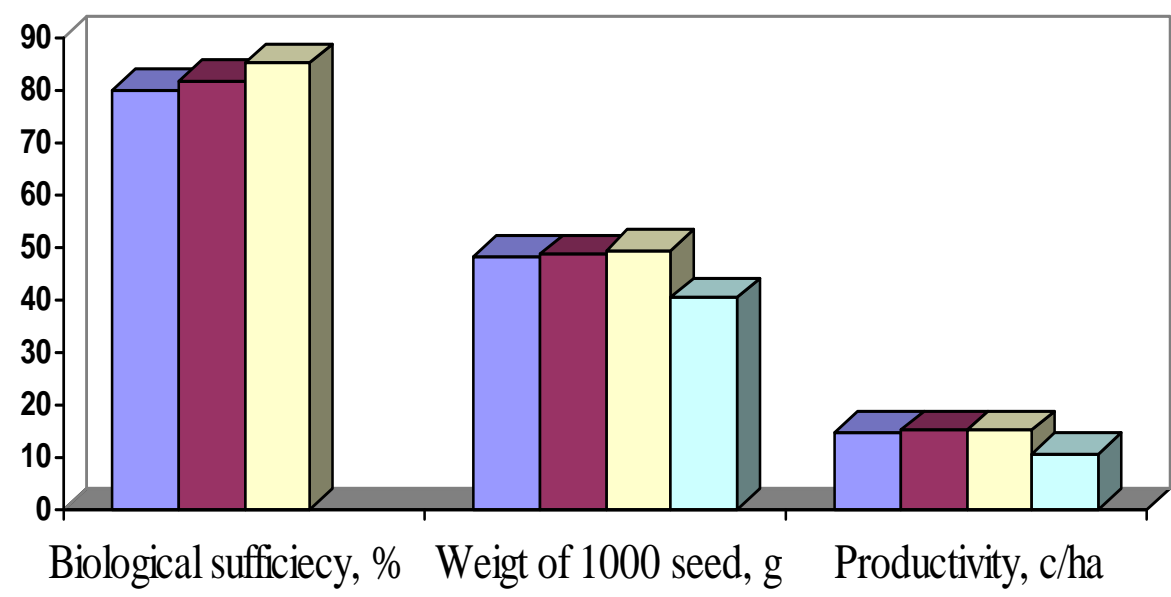

口 I variant Herkules $6 \%$ w .d.s. $0,5 \mathrm{l} / \mathrm{t}$

II variant Raksil Noviy $2,5 \%$ w.d.s. $0,7 \mathrm{l} / \mathrm{t}$

口 III variant Vial TrasT 12,9\% w.s.c. $0,3 \mathrm{l} / \mathrm{t}$

IV variant control

Figure 1: The insecticide preparations efficiency against to fusarial fading disease in mungbean.

Geographical spreading of bean diseases is depend on ecological condition. Fusarial root rotting areas average spreading is $12,7 \%$ this indicator makes 9,5 $12,7 \%$ in Tashkent region and in Jizzakh 13,3-14,9\%. Fusarial fading disease constitutes $33,3-34,5 \%$ in Tashkent and 29,9-32,7\% in Jizzakh.

According to the observations of anthracnose disease damage in the past years, it is defined decreasing to fusarial disease. In 2015 conducted phythopotologic experiments was conducted and as the test it decreased comparatively to 2014 . It was defined that $10,1 \%$ of plants were infected with fusarial root rotting, $29,6 \%$ fusarial fading, 9,0\% anthracnose diseases.

In Jizzakh fusarial root rotting disease constitutes 5,7 $10,7 \%$, 28,0-32,2\%, fusarial fading, $6,7-8,2 \%$ anthracnose disease. These indexes showed in Tashkent region $11,1-14,5 \%$ fusarial root rotting, 26,4-30,2\% fusarial fading, 5,5-15,1\% anthracnose disease.

In the condition of our republic the task of against to bean diseases was not learned completely, the owners of farms and private gardens sew seeds without insecticide. For the purpose determination of against fusarial diseases preparation's biologic sufficiency tested in the fields of Tashkent region TCETS which was allowed usage in the republic: Vial TrasT 12,9\% w.s.c. (tiabendazol+ tebukonazol)-0,3 l/t, Raksil Noviy 2,5\% w.d.s. (tebukonazol)-0,7 $\mathrm{l} / \mathrm{t}$ and Hercules $6 \%$ w.d.s.(tebukonazol)-0,5 l/t.

When the seedling controlled in the fields where sown the sort of Kakhrabo, $1 \mathrm{~m}^{2}$ place constitutes 25,3 this index is 35,3 Vial TrasT in the III type, 34,0 in the II Raksil Noviy type, 31,6 in the I type of Hercules were detected. Taking seedling much amount in the II and III type and the number of seeding was more 9-10 than in controlled type was characterized. In the controlled area germinated healthy seedling in the $1 \mathrm{~m}^{2}$, this indicator is 34,2 in III type, 32,8 in II type, 30,3 in type were detected. It is estimated that $7,3 \%$ plants diseases marks were in the controlled variant, 1,1-1,3 plants were injured in experiment variant (figure 1).

Insecticide preparation's sufficiency is $84,9 \%$ in the III type, $83,6 \%$ in II type, $82,2 \%$ in I variant. Used in the test of seed insecticide biologic efficiency influenced positively to the growth, development and productivity of a plant during the vegetation. As a result weight of 1000 corn constitute $35,0 \mathrm{~g}$ in the III type, 42,3 $\mathrm{g}$ in the II type, $42,2 \mathrm{~g}$ in the I type i.e for each type if control the amount of corn excelled in 7,8 $\mathrm{g}$ more corn will be harvested.

The exceeding productivity of harvest proved that it is important measure at the end of vegetation period. In the control type of each one ha field gave harvest of $11,1 \mathrm{c}$, $15,7 \mathrm{c}$ in the III type, 15,5 c in the II type, 15,4 c in the I type.

To fusarial disease sufficiency of bean type Radost was obviously manifested of studied seed spray fungicide. In the control type of Radost there are 27,6 seedlings in $1 \mathrm{~m}^{2}$, in the III test type 32,3 , in the II type 31,3 , in the I type 30,3 or have more $3-5$ each of them. Hence, in the comparatively to control variant more 9-11 seedling appeared, in the experiment variant number of injured plants were intensively decreased. Biologic efficiency of seeding insecticide is $80,1-85,1 \%$, the weight of 1000 crop is $8,9 \mathrm{~g}$ more than in the control type. If 10,4 c harvest get type of Radost in the experiment variant, there will be an opportunity to get $14,7-14,9$ c or $4 \mathrm{c}$ per ha. 


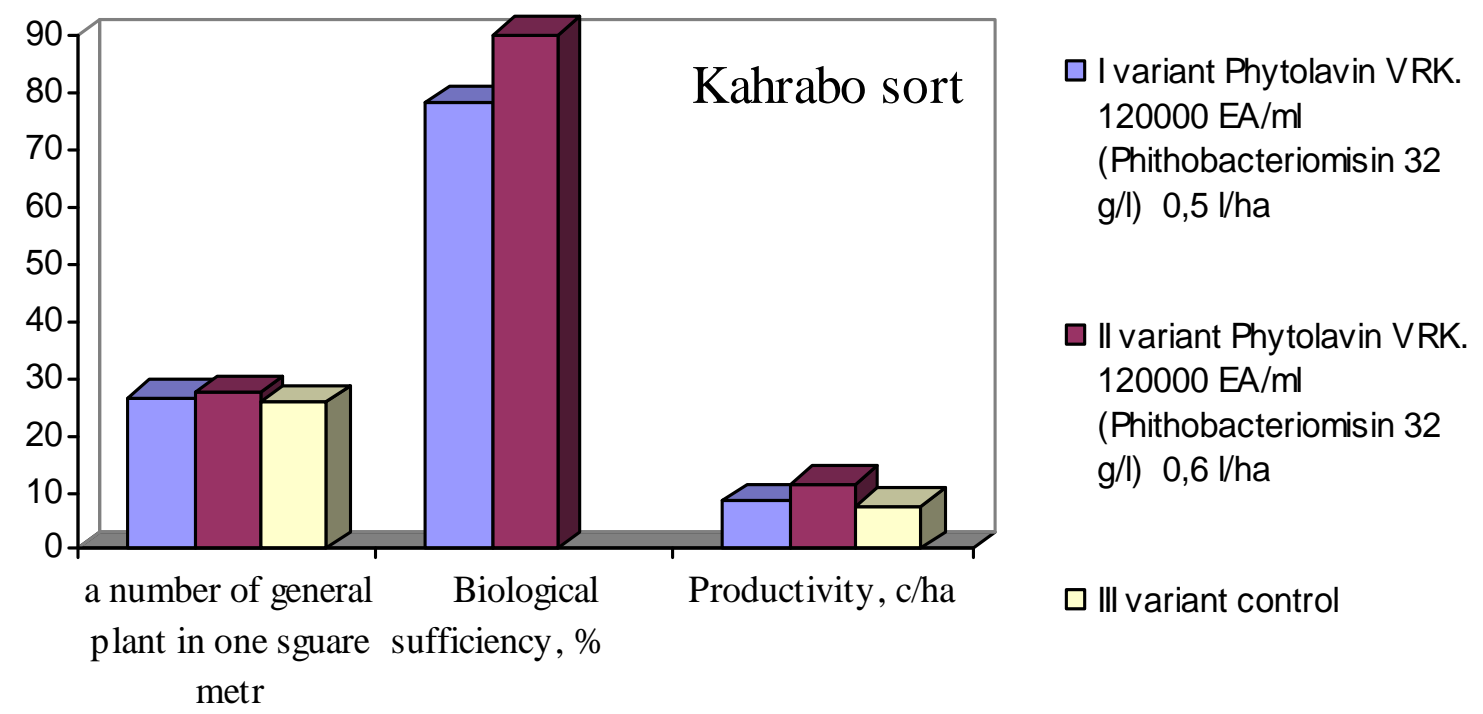

Figure2: The efficiency of Phitolavin fungicide against to anthracnose disease in mung bean

Table 1: Spreading mung bean diseases

\begin{tabular}{|c|c|c|c|c|c|c|c|c|c|c|c|c|c|c|}
\hline \multirow[t]{3}{*}{ Farming } & \multicolumn{2}{|c|}{ Implemented } & \multicolumn{6}{|c|}{2014} & \multicolumn{6}{|c|}{2015} \\
\hline & \multirow[t]{2}{*}{$\begin{array}{c}\text { Area, } \\
\text { ha }\end{array}$} & \multirow[t]{2}{*}{$\begin{array}{l}\text { Number } \\
\text { of plants }\end{array}$} & \multicolumn{2}{|c|}{$\begin{array}{l}\text { Fusarial root } \\
\text { rotting }\end{array}$} & \multicolumn{2}{|c|}{ Fusarial fading } & \multicolumn{2}{|c|}{ Anthracnose } & \multicolumn{2}{|c|}{$\begin{array}{l}\text { Fusarial } \\
\text { root rotting }\end{array}$} & \multicolumn{2}{|c|}{$\begin{array}{c}\text { Fusarial } \\
\text { fading }\end{array}$} & \multicolumn{2}{|c|}{ Anthracnose } \\
\hline & & & Num. & $\%$ & Num. & $\%$ & Num. & $\%$ & Num. & $\%$ & Num. & $\%$ & Num. & $\%$ \\
\hline \multicolumn{15}{|l|}{ Tashkent region } \\
\hline TCETS & 9,0 & 126 & 12 & 9,5 & 42 & 33,3 & 17 & 13,5 & 14 & 11,1 & 38 & 30,2 & 19 & 15,1 \\
\hline Kibrai disrtict & 86,0 & 110 & 14 & 12,7 & 38 & 34,5 & 7 & 6,4 & 16 & 14,5 & 29 & 26,4 & 6 & 5,5 \\
\hline \multicolumn{15}{|l|}{ Jizzakh region } \\
\hline Forish yullari, $f$ & 40,0 & 75 & 10 & 13,3 & 24 & 32,0 & 7 & 9,3 & 8 & 10,7 & 21 & 28,0 & 5 & 6,7 \\
\hline Azamat,f & 60,0 & 87 & 13 & 14,9 & 26 & 29,9 & 8 & 9,2 & 5 & 5,7 & 28 & 32,2 & 7 & 8,0 \\
\hline Obod diyor,f & 50,0 & 98 & 14 & 14,3 & 32 & 32,7 & 6 & 6,1 & 7 & 7,1 & 31 & 31,6 & 8 & 8,2 \\
\hline Total & 245,0 & 496 & 63 & 12,7 & 162 & 32,7 & 45 & 9,1 & 50 & 10,1 & 147 & 29,6 & 45 & 9,0 \\
\hline
\end{tabular}

(Tashkent and Jizzakh regions, 2014-2015 ss)

Against anthracnose disease in the bean Phitolavin VRK $120000 \mathrm{EA} / \mathrm{ml}$ fungicide tested for each ha.

Phitolavin VRK $120000 \mathrm{EA} / \mathrm{ml}$ - 0,5 I per hectare, 78,2\% efficiency against anthracnose disease in bean, Phitolavin VRK $120000 \mathrm{EA} / \mathrm{ml}-0,6$ I per hectare achieved $90,0 \%$ biologic efficiency. Usage Phitolavin fungicide 0,6 I per ha sharply decreased the disease of anthracnose among beans and increased 3,9 c per ha rather than control (figure 2).

In as much as there have been the disease like fusarial root rotting, fading and anthracnose when it sown after wheat as repeated crop in Tashkent and Jizzakh region. To decrease their damage and to improve the quality of the product is important usage insecticide against to disease Vial TrasT-0,3 l/t, the process of Raksil Noviy-0,7 l/t and Hercules-0,5 l/t, usage of Phitolavin-0,6 I will decrease the damage of anthracnose I the vegetation period.

\section{ANNOTATION}

In this article it was studied biologic efficiency of Hercules, Raksil Noviy, Vial TrasT preparation against fusarial root rotting and fading disease effect of productivity among Kakhrabo and Radost types. Biologic efficiency of preparation for Hercules constitutes $82,2 \%$, $83,3 \%$ for Raksil Noviy, $84,9 \%$ for Vial TrasT constitute and productivity by types 15,$4 ; 15,5$ and $15,7 \mathrm{c}$ per ha. Usage of insecticide the seed of bean before sowing will increase the productivity 4,5 c per ha in Kakhrabo type, $4,1 \mathrm{c}$ per ha in the Radost type. Biologic efficiency of 
046 Int. Res. J. Agric. Sci. Soil Sci.

Phitolavin preparation against anthracnose disease was $78,2-90,0 \%$.

\section{REFERENCE}

Chumakov AE (1974). Fungi diseases. The main methods of phythophatologic researches. - M: Colos. p. 70-106.

Hasanov BO, Ochilov RO, Gulmurodov RA (2009). Mung bean and pea diseases. Vegetable, potato and melon field crops diseases and fight to them. - Tashkent.p. 109-115.

Hujaev ShT (2004). Methodic instructions on testing fungicide, insecticide acarapidosis and biologic active substances. II press. Tashkent. p. 69

Kurbonov GK (1995). Getting quality and much yield of wheat corns. Uzbekistan farm-industry complex scientific provider (scientific session materials) II press. - Tashkent.p. 42.

Otaboeva Kh, Tolipov M (1995). Breeding repeated corn products.// Agriculture of Uzbekistan. №4. p. 35
Otaboeva Kh, Umarov Z, Massino I, Kodirjonov O (2000). General characteristics of luminous crops -Tashkent. p. 128-136

Sheraliev ASh, Sattarova RK, Rakhimov UKh (2008). Mung bean diseases. Farming phythophatology. Tashkent. p 61-63.

Singli SN, Srivastava SK (1987). Effect of phosphorus application on the severity of some important foliar diseases of mung bean and urdbean. Agr.Sc.Dig. -.7.1:47-51.

Yunusov B (1995). Improvement factors of luminous corn selection and seeds in irrigated lands. Uzbekistan farm-industry complex scientific provider (scientific session materials) II press.Tashkent. p. 82-84. 